\title{
Performance, Microbial Populations, and Jejunal Morphology of Broilers Supplemented with Nano-Encapsulated Graviola Leaf Extract
}

\author{
U. Maesaroh, N. D. Dono, \& Zuprizal* \\ Department of Animal Nutrition and Feed Science, Faculty of Animal Science, Universitas Gadjah Mada \\ Jalan Fauna No. 03 Bulaksumur, Yogyakarta 55281, Indonesia \\ *Corresponding author: zuprizal@ugm.ac.id \\ (Received 12-04-2021; Revised 20-07-2021; Accepted 16-08-2021)
}

\begin{abstract}
This research was conducted to investigate the effects of adding nano-encapsulated graviola (Annona muricata Linn.) leaf extract (NGLE) to drinking water on microbial populations, jejunal morphology, and growth performance of broilers. A total of 300 seven-day-old Lohmann male broilers were allocated into 6 treatments with 5 replications and 10 chicks in each replicate pen. All birds were given the same basal diet but given drinking water treated with: drinking water only as a negative control (T1), drinking water $+25 \mathrm{mg} / \mathrm{L}$ Tetracycline (T2), drinking water $+15 \mathrm{~mL} / \mathrm{L} \mathrm{GLE}$ (T3), drinking water $+30 \mathrm{~mL} / \mathrm{L}$ GLE (T4), drinking water $+15 \mathrm{~mL} / \mathrm{L}$ NGLE (T5), or drinking water $+30 \mathrm{~mL} / \mathrm{L}$ NGLE (T6). Variables observed in the current study included: body weight gain (BWG), final body weight (FBW), feed conversion ratio (FCR), feed intake (FI), carcass percentage, jejunal lactic acid bacteria (LAB), jejunal coliform bacteria, villus height and width, crypt depth, and crypt depth ratio. All variable data were statistically analyzed using a completely randomized design with one-way arrangement. Results showed that the addition of NGLE in drinking water improved $(p<0.05)$ jejunal morphology, jejunal LAB, and growth performance of broiler chickens. The height of jejunal villus and population of jejunal LAB increased $(p<0.01)$ when NGLE up to a dose of $15 \mathrm{~mL} / \mathrm{L}$ was added into the drinking water. Supplementing $15 \mathrm{~mL} / \mathrm{L}$ NGLE reduced $(\mathrm{p}<0.01)$ feed conversion ratio and improved $(\mathrm{p}<0.01)$ final body weight and carcass production compared with the other treatments. It is concluded that supplementation of $15 \mathrm{~mL} / \mathrm{L}$ NGLE might be useful as an alternative for antibiotics growth promoters in poultry.
\end{abstract}

Keywords: broiler chicken; growth performance; jejunal morphology; microbial populations; nanoencapsulation of Graviola leaf extract

\section{INTRODUCTION}

Antibiotics at sub-therapeutic dosages are used widely in poultry production systems to control subclinical diseases, inhibit enteric pathogens' growth, maintain gut health, improve growth performance, and minimize mortality by preventing infections (Alonge et al., 2017). However, the uncontrolled use of antibiotics in poultry diets leads to the accumulative residues in the products of animals, reduction in the population of beneficial intestinal microflora, the resistance of pathogens to multiple or all antibiotics (superbug), and imbalance population of normal microflora in the gut (Cherkasov et al., 2008; Sugiharto \& Ranjitkar, 2019). Today, public worries over routine uses of antibiotics have been increasing about the possible accumulation of antibiotic residues in animal bodies, animal products, and the environment (Wachira et al., 2011; Sen et al., 2012). The European Union (EU) countries started to remove all growth-promoting antibiotics in poultry diets in 2006. In Indonesia, antibiotics as a growth promoter in poultry diets have been banned since January 2018 (Amalia \& Adisasmito, 2017). This decision was in line with the policy of many countries to restrict the use of antibiotics as growth promoters (AGPs) in poultry (Sugiharto, 2016).

With the removal of antibiotics as growth promoters in poultry diets, poultry nutritionist and the poultry industry must focus on exploring alternative substances to enhance intestinal health, control the growth of harmful bacteria, and improve the growth performance of broiler chickens. One of the potential alternatives for antibiotics is natural medicinal products from herbs (Phyto biotic). Previous studies reported that medicinal herbs and essential oils had been used as feed additives to enhance growth performance and digestive function as well as to control the growth of harmful microbes in the gut of broiler chickens (Dei et al., 2008; Leusink et al., 2010). Bioactive compounds contained in the medicinal herbs were beneficial in reducing the growth and population of pathogenic bacteria in the gut (Hosseini et al., 2019; Gharechopogh et al., 2021), and 
potentially improve the growth performance of broiler chickens (Dono, 2013). Graviola (Annona muricata Linn.) leaf has long been appreciated as an important source of bioactive compounds of medicinal value, since they contain a variety of useful bioactive metabolites, such as flavonoids, alkaloids, terpenoids, saponins, coumarins, lactones, anthraquinones, tannins, cardiac glycosides, phenols, and phytosterols (Gavamukulya et al., 2014; Sugayana et al., 2016). It has also been reported that bioactive compounds in graviola leaf extract could beneficially improve gut health, stimulate the immune system, enhance digestive products utilization, and improve broiler chickens' performance (Jiwuba et al., 2017).

The technology of nanoparticles such as chitosan nanoparticles that are cross-linked to sodium tripolyphosphate (STPP) is beneficial for maximizing bioactive compounds' transports from natural medicinal products to improve their absorptions (Calvo et al., 1997). Chitosan nanoparticles can be used as drug carriers for natural medicinal products and have some advantages to increase drug solubility, protection from toxicity, as well as protection from physical or chemical degradation, and enhance efficacy. Because of their small sizes, they can pass through barriers in vivo and deliver a drug to the lesion site to enhance the drug efficacy (Buzea et al., 2007). Chitosan also has various bioactivities, such as antibacterial activities and immuno-enhancing effects that can improve the effects of herbal products (Nouri, 2019).

The nano-encapsulation technology with chitosan cross-linked to sodium tripolyphosphate protects bioactive compounds from damage in the gastrointestinal tract of broilers. The technology of nanoparticles will protect bioactive compounds in Phyto biotics and increase their durability. The liquid Phyto biotics added to drinking water had higher homogeneity and durability than the powdered Phyto biotics added in feed. The combination of Phyto biotics (graviola leaf extract) with chitosan nanoparticles technology in drinking water for broiler chickens has never been studied before. Therefore, the objective of this study was to determine the effect of nano-encapsulated graviola leaf extract with chitosan cross-linked to sodium tripolyphosphate on microbial populations, jejunal morphology, and growth performances of broiler chickens.

\section{MATERIALS AND METHODS}

\section{Ethical Approval}

This study used a standard procedure that has been certified by the ethical board from the Faculty of Veterinary Medicine, Universitas Gadjah Mada, Yogyakarta, Indonesia, with certification number 0056/ EC-FKH/Eks/2019.

\section{Preparation of Ethanolic Extract of Graviola Leaf}

Fresh graviola leaves were cut into small pieces and dried in an oven at $55{ }^{\circ} \mathrm{C}$ for $72 \mathrm{~h}$. The dried sliced-leaves were then milled $(2 \mathrm{~mm})$ with a Wiley mill to facilitate the extraction process. A total of $200 \mathrm{~g}$ of graviola-leaves meal was weighed using analytical scales (Ohaus GA200D, Pine Brook, New Jersey, USA). The samples were placed in a beaker glass and then macerated with $96 \%$ ethanol. The liquid-extract solution was evaporated until free from ethanol solution using a water bath (Memmert, Schwabach, Germany) at 60 ${ }^{\circ} \mathrm{C}$ for $3 \mathrm{~h}$ until the extract was viscous. Graviola-leaf extract (GLE) was obtained by dissolving $2 \%$ aqueous graviola-leaf extract using distilled water.

\section{Preparation of Nano-Encapsulated Graviola-Leaf Extract}

Nano-encapsulation of graviola-leaf extracts (NGLE) were formulated by ionic gelation method, a cross-linking of chitosan (CS) with sodium tripolyphosphate (STPP) according to Sari et al. (2018) with slight modifications in the concentration ratio of CS:STPP:herbal-plant extract. A total of $0.2 \mathrm{~g}$ chitosan was dissolved in $100 \mathrm{~mL}$ of distilled water which was added with $1 \%$ acetic acid. The solution of graviola-leaf extract was added into chitosan solution with a ratio of 1:1. In addition, $0.04 \mathrm{~g}$ of STPP was dissolved in $40 \mathrm{~mL}$ of distilled water. The solution of STPP was then added into the solution of CS-graviola-leaf extract with a constant magnetic stirring (700 rpm) for $30 \mathrm{~min}$ at room temperature. The formula of CS-STPP-graviola-leaf extract was centrifuge at $3500 \mathrm{rpm}$ for $30 \mathrm{~min}$.

The optimization formula of nano-encapsulation of graviola-leaf extracts was presented in Table 1. The volumes of CS-STPP solutions used were chosen so as to give chitosan:STPP weight ratios $(\mathrm{w} / \mathrm{w})$ of 2:0.020, 2:0.013, 2:0.010, 1:0.020, 1:0.013, and 1:0.010, respectively, as were presented in Table 1 . The above solution was stirred for $30 \mathrm{~min}$ to generate chitosan nanoparticlegraviola leaf extract suspensions (CS-NPs-GLE).

\section{Phytochemical Screening}

Phytochemical tests were done on the graviola-leaf extract and nanoencapsulation of graviola leaf extract using standard procedures to identify the constituents as described by Sofowora (1993).

Test for total phenolics. The graviola leaf extract was weighed accurately at the weight of $100 \mathrm{mg}$ and dissolved in $100 \mathrm{~mL}$ of distilled water. A total of $1.5 \mathrm{~mL}$ of this solution were transferred into a test tube. Further, 1 $\mathrm{mL}$ of $2 \mathrm{~N}$ Folin-Ciocalteu and $2 \mathrm{~mL}$ of $20 \% \mathrm{Na}_{2} \mathrm{CO}_{3}$ solution were added and ultimately the volume was made up to $10 \mathrm{~mL}$ with distilled water. The above solution was allowed to stand for 2 hours, after which the absorbance was measured at $760 \mathrm{~nm}$. Total phenolic contents were estimated using a standard calibration curve obtained from various diluted concentrations of gallic acid.

Test for flavonoids. To test for flavonoid in the extract obtained from the leaves of graviola, $0.5 \mathrm{~g}$ of each extract was added into a tube containing $10 \mathrm{~mL}$ of distilled water. A total of $5 \mathrm{~mL}$ of dilute ammonia solution were added to a portion of the aqueous filtrate of each plant extract, followed by the addition of $1 \mathrm{~mL}$ of concen- 
Table 1. Formulation of graviola leaf extract-loaded chitosan nanoparticles cross-linked to sodium tripolyphosphate

\begin{tabular}{ccccc}
\hline Formulation & CS : STPP ratio $(\mathrm{mL})$ & Graviola leaf extract $(\mu \mathrm{L})$ & CS concentration $(\% w / v)$ & STPP concentration $(\% w / v)$ \\
\hline A & $02: 0.020$ & 2000 & 0.002 & 0.001 \\
B & $02: 0.013$ & 2000 & 0.002 & 0.001 \\
C & $02: 0.010$ & 2000 & 0.002 & 0.001 \\
D & $01: 0.020$ & 1000 & 0.002 & 0.001 \\
E & $01: 0.013$ & 1000 & 0.002 & 0.001 \\
F & $01: 0.010$ & 1000 & 0.002 & 0.001 \\
\hline
\end{tabular}

Note: CS= Chitosan; SSTPP= Sodium tripolyphosphate. Formula A, B, and C were produced by dropping the STPP solution into CS solution at 2 mL and GLE at $2 \mathrm{~mL}$; while formula D, E, and F were prepared by pouring the STPP solution into CS solution at $1 \mathrm{~mL}$ and GLE at $1 \mathrm{~mL}$.

trated $\mathrm{H}_{2} \mathrm{SO}_{4}$. The above solution was allowed to stand for 2 hours, after which the absorbance was measured at $760 \mathrm{~nm}$. The yellow color indicated the presence of flavonoids in each extract.

\section{Birds, Diets, and Experimental Design}

The research was conducted for 35 days (5 weeks) using 300 seven-day-old Lohmann male broiler chicks. The birds were allocated into six treatment groups with five replications and ten chicks in each replicate pen. All of the birds were given the same basal diet, but with different treatments: drinking water only as a negative control (T1), drinking water $+25 \mathrm{mg} / \mathrm{L}$ Tetracycline (T2), drinking water $+15 \mathrm{~mL} / \mathrm{L}$ GLE (T3), drinking water +30 $\mathrm{mL} / \mathrm{L}$ GLE (T4), drinking water + $15 \mathrm{~mL} / \mathrm{L}$ NGLE (T5), or drinking water $+30 \mathrm{~mL} / \mathrm{L}$ NGLE (T6). Birds were given diets and drinking water ad-libitum throughout the research. Formulation and nutrient compositions for the basal diets are presented in Table 2 .

\section{Growth Performance}

The final body weights of individual birds, average body weight gain, feed intake, and feed conversion ratio were calculated for the overall study period (days 8-35). Daily mortality was recorded, and due importance was given to mortality while calculating feed intake and feed conversion.

\section{Microbial Populations}

Thirty birds were randomly selected (5 birds from each treatment group) and slaughtered according to Islamic law at the 35 days rearing period of the trial to study the intestinal microflora and morphology. Samples of the contents from the jejunal (from the distal end of the duodenum to the Meckel's diverticulum) were collected with gentle press and placed in sterile plastics bottles. The samples were immediately placed in the freezer $\left(-20^{\circ} \mathrm{C}\right)$ for further analysis. The jejunal microflora were analyzed using a culture technique described by Shang et al. (2016) with slight modifications. Dilutions of the contents from the jejunal were inoculated in duplicate onto selective agars: Brilliance E. coli/coliform Selective agar (Oxoid, Basingstoke, Hampshire, UK) for Escherichia coli incubated at 37 ${ }^{\circ} \mathrm{C}$ for 24 h; Peptone Glucose Yeast (PGY) agar (Difco, USA) for Lactic acid bacteria incubated at $37{ }^{\circ} \mathrm{C}$ for 48 h; and Salmonella shigella agar (SS) (Oxoid, Basingstoke, Hampshire, UK) for Salmonella $s p$ incubated at $37{ }^{\circ} \mathrm{C}$ for $24 \mathrm{~h}$. Microbial population counts were expressed as $\log 10$ colony-forming units (CFU) $\mathrm{g}^{-1}$ wet digesta for each jejunal content sample.

\section{Morphology of Jejunal Villi}

The samples used for jejunal morphology were taken in a $6 \mathrm{~cm}$ section of the jejunum from Meckel's diverticulum. The jejunal samples were immediately fixed into $10 \%$ formalin buffer solution for further analyses. The jejunal was histologically prepared using Bouin's, alcohol, toluol, xylol, paraffin, hematoxylin-eosin (HE) dye solutions, and Image Raster software version 4.0.5. The jejunal sample was dehydrated in a series of alcohol with increasing concentrations (35\%, 50\%, 70\%, and 95\%) and embedded in paraffin. The jejunum was then

Table 2. Composition and nutrient contents of the basal diet for pre-starter, starter, and finisher periods

\begin{tabular}{lr}
\hline Items & Content \\
\hline Diet composition (\% as fed) & \\
Corn & 58.50 \\
Soybean meal & 27.50 \\
Meat and bone meal & 7.00 \\
Rice bran & 2.50 \\
Crude palm oil & 2.60 \\
Vitamins and minerals premix & 2.50 \\
CaCO & 1.00 \\
L-lysine HCl & 0.20 \\
Dl-methionine & 0.20 \\
NaCl & 0.25 \\
Total & 100.00 \\
Calculated provisions & \\
Metabolic energy (kcal/kg) & 3159.24 \\
Crude protein (\%) & 21.04 \\
Ether extract (\%) & 5.65 \\
Crude fiber (\%) & 3.16 \\
Phosphorus. available (\%) & 0.68 \\
Calcium (\%) & 1.19 \\
Lysine (\%) & 1.33 \\
Methionine (\%) & 0.53 \\
Threonine (\%) & 0.76 \\
\hline
\end{tabular}

Note: *Vitamins and minerals premix content per kg: Calcium $32.5 \%$, Phosphorus 1.0\%, Iron $6 \mathrm{~g}$, Manganese $4 \mathrm{~g}$, Iodine $0.075 \mathrm{~g}$, Copper $0.3 \mathrm{~g}$, Zinc $3.75 \mathrm{~g}$, Vitamin B12 $0.5 \mathrm{mg}$, Vitamin D3 50,000 IU. 
fixed using Bouin's solution for $12 \mathrm{~h}$. Villi tissues were then cut into $4 \mu \mathrm{m}$ slices prepared using microtome stained by the HE method as described by Thanh et al. (2009). The observations of jejunal morphology were conducted using an electron transmission microscope with 4X magnification equipped with an Optilab digital camera (Optilab Advance, Miconos, Indonesia).

\section{Statistical Analysis}

The variable data were statistically analyzed using a completely randomized design with a one-way arrangement. Means among treatments were statistically separated by Duncan post-hoc test. SPSS version 2.2 Software was used for all statistical analysis, with significance statements were based on a $\mathrm{p}<0.05$.

\section{RESULTS}

\section{Particle Size and Phytochemical Screening}

The particle size of graviola-leaf extracts (GLE) and nano-encapsulation of graviola-leaf extracts (NGLE) are presented in Table 3. GLE was found to have a particle size of $2708.13 \pm 173.36 \mathrm{~nm}$. The particle size of GLEloaded by chitosan-sodium tripolyphosphate nanoparticles was found to be $234.00 \pm 21.50 \mathrm{~nm}$ in optimum formula of CS-GLE-STPP ratio 1:1:0.01 (Formula F, Table 1). The GLE was found to contain $2.40 \%$ of phenolics and $49.18 \%$ of flavonoids; NGLE contained $0.97 \%$ of phenolics and $23.99 \%$ of flavonoids (Table 3 ).

\section{Growth Performance}

The effect of supplementation of both GLE and NGLE on the growth performances of broiler chickens is summarized in Table 4. Supplementation of drinking water with GLE at a dose of $15 \mathrm{~mL} / \mathrm{L}$ increased $(\mathrm{p}<0.01)$ final body weight and carcass percentage. The increased dose of GLE supplementation up to $30 \mathrm{~mL} / \mathrm{L}$ increased final body weight simultaneously $(p<0.01)$. However, supplementation of drinking water with NGLE at a dose of $15 \mathrm{~mL} / \mathrm{L}$ not only increased weight gain but also reduced $(p<0.01)$ feed conversion ratio and improved $(p<0.01)$ body weight, final body weight, and carcass production resulting in the better improvement than those of non-supplemented birds or antibiotic-supplemented birds.

\section{Microbial Populations}

Table 5 summarizes the effect of supplementation of both GLE and NGLE on the microbial population of broiler chickens. Supplementation of GLE at a dose of $15 \mathrm{~mL} / \mathrm{L}$ in the drinking water increased $(\mathrm{p}<0.01)$ the population of jejunal LAB and reduced $(p<0.01)$ the population of coliform bacteria, resulting in the better improvement when compared to the negative control. Meanwhile, broiler chickens supplemented with GLE at a dose of $15 \mathrm{~mL} / \mathrm{L}$ in the drinking water had higher $(p<0.01)$ jejunal LAB than those fed with Tetracycline. Supplementation of drinking water with NGLE at a dose of $15 \mathrm{~mL} / \mathrm{L}$ also reduced $(\mathrm{p}<0.01)$ jejunal coliform bacteria, similar to the effect of Tetracycline supplementation in the feed.

\section{Jejunal Morphology}

Table 6 shows the effect of GLE and NGLE supplementations on the jejunal morphology of broiler chickens. Broiler chickens fed diets supplemented with NGLE at a dose of $15 \mathrm{~mL} / \mathrm{L}$ had higher $(\mathrm{p}<0.01)$ villus height in the jejunum (Figure 1) when compared to control chickens without NGLE supplementation, birds supplemented with GLE, or birds supplemented with antibiotic. Furthermore, supplementation of NGLE at

Table 3. Phytochemical screening and particle size of nano-encapsulated graviola leaf extract compared with graviola leaf extract

\begin{tabular}{|c|c|c|c|}
\hline \multirow{2}{*}{ Samples } & \multicolumn{2}{|c|}{ Secondary metabolite } & \multirow{2}{*}{ Particle size (nm) } \\
\hline & Total phenolics (\% b/v) & Total flavonoids $(\% \mathrm{~b} / \mathrm{v})$ & \\
\hline Graviola leaf extract (GLE) & 2.4 & 49.18 & $2708.13 \pm 173.36$ \\
\hline Nano-encapsulation of GLE & 0.97 & 23.99 & $234.00 \pm 21.50$ \\
\hline
\end{tabular}

Table 4. Growth performance of 35 days old male broiler chickens supplemented with nano-encapsulated graviola leaf extract

\begin{tabular}{cccccc}
\hline \multirow{2}{*}{ Treatments } & \multicolumn{5}{c}{ Variables } \\
\cline { 2 - 6 } & Final body weight $(\mathrm{g})$ & Weight gain $(\mathrm{g})$ & Feed intake $(\mathrm{g})$ & Feed conversion & Carcass percentage $(\%)$ \\
\hline T1 & $1714.38 \pm 20.40^{\mathrm{e}}$ & $1584.66 \pm 20.14^{\mathrm{c}}$ & $2575.82 \pm 224.66$ & $1.61 \pm 0.13^{\mathrm{a}}$ & $64.89 \pm 1.52^{\mathrm{d}}$ \\
T2 & $1737.71 \pm 35.72^{\mathrm{de}}$ & $1615.07 \pm 38.42^{\mathrm{bc}}$ & $2464.58 \pm 106.43$ & $1.52 \pm 0.82^{\mathrm{ab}}$ & $65.75 \pm 1.59^{\mathrm{cd}}$ \\
T3 & $1784.25 \pm 31.66^{\mathrm{cd}}$ & $1635.68 \pm 32.29^{\mathrm{bc}}$ & $2574.22 \pm 146.34$ & $1.55 \pm 0.89^{\mathrm{ab}}$ & $67.40 \pm 0.58^{\mathrm{bc}}$ \\
T4 & $1820.60 \pm 30.97^{\mathrm{bc}}$ & $1650.98 \pm 16.68^{\mathrm{b}}$ & $2451.51 \pm 91.08$ & $1.48 \pm 0.51^{\mathrm{ab}}$ & $67.77 \pm 2.04^{\mathrm{bc}}$ \\
T5 & $1859.54 \pm 56.56^{\mathrm{ab}}$ & $1704.94 \pm 56.84^{\mathrm{a}}$ & $2489.10 \pm 138.13$ & $1.46 \pm 0.82^{\mathrm{b}}$ & $68.46 \pm 1.47^{\mathrm{ab}}$ \\
T6 & $1880.16 \pm 39.22^{\mathrm{a}}$ & $1709.37 \pm 46.28^{\mathrm{a}}$ & $2517.33 \pm 100.08$ & $1.47 \pm 0.76^{\mathrm{b}}$ & $70.12 \pm 1.20^{\mathrm{a}}$ \\
SEM & 12.81 & 57.90 & 25.24 & 0.02 & 0.40 \\
P-value & $<0.01$ & $<0.01$ & 0.62 & $<0.05$ & $<0.01$
\end{tabular}

Note: GLE= graviola leaf extract; T1=drinking water without feed additive as a negative control, $\mathrm{T} 2=\mathrm{drinking}$ water $+\mathrm{Tetracycline} 25 \mathrm{mg} / \mathrm{L}$ drinking water as positive control, T3=drinking water $+15 \mathrm{~mL} / \mathrm{L}$ GLE, T4=drinking water $+30 \mathrm{~mL} / \mathrm{L}$ GLE, T5= drinking water $+15 \mathrm{~mL} / \mathrm{L}$ nano-encapsulation

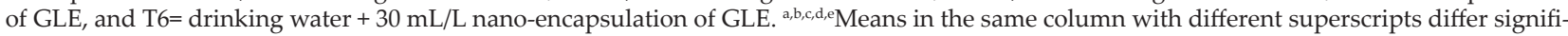
cantly $(\mathrm{p}<0.05)$. 
a dose of $15 \mathrm{~mL} / \mathrm{L}$ increased $(\mathrm{p}<0.01)$ the ratio of villus width and crypt depth.

\section{DISCUSSION}

\section{Particle Size and Phytochemical Screening}

The particle size of NGLE was found to be 234.00 $\pm 21.50 \mathrm{~nm}$, and these results are appropriate with the requirement of chitosan nanoparticles, which should be less than $500 \mathrm{~nm}$. This size indicates the potential of graviola leaf extract loaded by chitosan nanoparticles, possibly as drug carries because of their small sizes. Nanotechnology is needed to protect the bioactive compounds from physical and chemical degradation (Saraf, 2010; Bonifácio et al., 2014). It also has maximized bioactive compounds from herbal extracts in transportation for effective absorption in the animal's gastrointestinal tract (Calvo et al., 1997).

The bioactive compounds of graviola-leaf extract, such as flavonoids and phenolic compounds, were considered to be most important. The extracts of GLE

Table 5. Microbial populations of 35 days old male broiler chickens supplemented with nano-encapsulated graviola leaf extract

\begin{tabular}{lccc}
\hline \multirow{2}{*}{ Treatments } & \multicolumn{3}{c}{ Microbial populations (log cfu/g) } \\
\cline { 2 - 4 } & $\begin{array}{c}\text { Lactic acid } \\
\text { bacteria }\end{array}$ & Coliform & Salmonella sp. \\
\hline T1 & $3.10 \pm 0.12^{\mathrm{c}}$ & $3.97 \pm 0.08^{\mathrm{a}}$ & $\mathrm{ND}$ \\
$\mathrm{T} 2$ & $3.50 \pm 0.04^{\mathrm{b}}$ & $3.14 \pm 0.16^{\mathrm{b}}$ & $\mathrm{ND}$ \\
$\mathrm{T} 3$ & $3.60 \pm 0.10^{\mathrm{b}}$ & $3.60 \pm 0.12^{\mathrm{c}}$ & $\mathrm{ND}$ \\
$\mathrm{T} 4$ & $3.58 \pm 0.27^{\mathrm{b}}$ & $3.38 \pm 0.06^{\mathrm{d}}$ & $\mathrm{ND}$ \\
$\mathrm{T} 5$ & $4.17 \pm 0.15^{\mathrm{a}}$ & $3.10 \pm 0.09^{\mathrm{d}}$ & $\mathrm{ND}$ \\
T6 & $4.18 \pm 0.14^{\mathrm{a}}$ & $3.17 \pm 0.12^{\mathrm{d}}$ & $\mathrm{ND}$ \\
SEM & 0.09 & 0.08 & - \\
P-value & $<0.01$ & $<0.01$ & - \\
\hline
\end{tabular}

Note: GLE= graviola leaf extract; $\mathrm{T} 1=$ drinking water without feed additive as a negative control, $\mathrm{T} 2=$ drinking water + Tetracycline 25 $\mathrm{mg} / \mathrm{L}$ drinking water as positive control, T3=drinking water +15 $\mathrm{mL} / \mathrm{L} \mathrm{GLE}, \mathrm{T} 4=$ drinking water $+30 \mathrm{~mL} / \mathrm{L}$ GLE, $\mathrm{T} 5=$ drinking water $+15 \mathrm{~mL} / \mathrm{L}$ nano-encapsulation of GLE, and T6= drinking water + $30 \mathrm{~mL} / \mathrm{L}$ nano-encapsulation of GLE. a,b,c,de Means in the same column with different superscripts differ significantly $(\mathrm{p}<0.05)$. were rich in flavonoid and phenolic compounds (Table 3) which have wide pharmacological effects, such as antioxidants and antibacterial activity. Flavonoids are known to prevent oxidative cell damage, have antimicrobial properties, and also have anti-cancer activity to inhibit all stages of carcinogenesis (Vijayameena et al., 2013; Pieme et al., 2014; Moghadamtousi et al., 2015). Flavonoids possess antioxidant properties (George et al., 2012; Nawwar et al., 2012), protect against allergies (Ross, 2010), inflammation (Hassan et al., 2013; Monigatti et al. (2013), microbes (Vieira et al., 2010; Solomon-Wisdom et al., 2014), viruses (Helfer et al., 2014), and tumor (Hamizah et al., 2012). The important phenolic compounds found in graviola leaves include quercetin (Nawwar et al., 2012) and gallic acid (CorreaGordillo et al., 2012). Phenolic compounds are considered to be the major phytochemicals responsible for antioxidant activity (George et al., 2014). The mechanism of antioxidant activity of graviola leaf is due to their redox properties, carboxylic groups, and the presence of conjugated ring structures, which have been reported to inhibit lipid peroxidation (Rice-Evans et al., 1995). The graviola leaf extracts were found to be rich in phenolic compounds, which have antimicrobial activity. It has been demonstrated that phenolic compounds inhibit and change the microbial enzymes by binding the membrane protein or hydrogen with vital proteins (Radji et al., 2015).

\section{Growth Performance}

The supplementation of NGLE optimized the growth performance of broiler chickens compared with the other treatments. In this study, the addition of NGLE improved lactic acid bacteria and suppressed the growth of pathogenic bacteria (Table 5) with a mechanism of a bioactive compound of graviola leaf extracts as an antibacterial agent. The mechanism of antibacterial activity could be attributed to the decreased intestinal $\mathrm{pH}$, that was important to limit the growth of pathogenic bacteria, which were known to be intolerant to acidic pH environment (Fascina et al., 2012). With the decrease in pathogenic bacteria population, the accumulation of the microbial toxins in the intestine would

Table 6. Jejunal morphology $(\mu \mathrm{m})$ of 35 days old male broiler chickens supplemented with nano-encapsulated graviola leaf extract

\begin{tabular}{ccccc}
\hline \multirow{2}{*}{ Treatments } & \multicolumn{4}{c}{ Jejunal morphology } \\
\cline { 2 - 5 } & Villus height & Villus width & Crypt depth & Crypt depth ratio \\
\hline T1 & $1448.43 \pm 61.79^{\mathrm{b}}$ & $188.59 \pm 55.50^{\mathrm{ab}}$ & $267.48 \pm 48.29$ & $5.16 \pm 1.34^{\mathrm{c}}$ \\
T2 & $1502.91 \pm 70.34^{\mathrm{b}}$ & $205.74 \pm 36.91^{\mathrm{ab}}$ & $254.79 \pm 80.61$ & $5.53 \pm 1.52^{\mathrm{bc}}$ \\
T3 & $1530.09 \pm 59.68^{\mathrm{b}}$ & $168.76 \pm 28.72^{\mathrm{b}}$ & $232.15 \pm 49.12$ & $6.07 \pm 0.69^{\mathrm{bc}}$ \\
T4 & $1531.48 \pm 90.83^{\mathrm{b}}$ & $200.18 \pm 50.71^{\mathrm{ab}}$ & $217.59 \pm 46.12$ & $6.69 \pm 1.20^{\mathrm{ab}}$ \\
T5 & $1823.86 \pm 23.49^{\mathrm{a}}$ & $257.95 \pm 51.40^{\mathrm{a}}$ & $253.15 \pm 47.60$ & $6.86 \pm 1.01^{\mathrm{ab}}$ \\
T6 & $1791.67 \pm 92.42^{\mathrm{a}}$ & $213.11 \pm 10.80^{\mathrm{ab}}$ & $240.89 \pm 36.83$ & $7.52 \pm 0.74^{\mathrm{a}}$ \\
SEM & 29.6 & 8.63 & 9.34 & 0.22 \\
P-value & $<0.01$ & $<0.05$ & 0.72 & $<0.05$ \\
\hline
\end{tabular}

Note: GLE= graviola leaf extract; T1=drinking water without feed additive as a negative control, T2=drinking water + Tetracycline $25 \mathrm{mg} / \mathrm{L}$ drinking water as positive control, T3=drinking water $+15 \mathrm{~mL} / \mathrm{L} \mathrm{GLE}$, T4=drinking water $+30 \mathrm{~mL} / \mathrm{L}$ GLE, T5= drinking water $+15 \mathrm{~mL} / \mathrm{L}$ nano-encapsulation of GLE, and T6= drinking water $+30 \mathrm{~mL} / \mathrm{L}$ nano-encapsulation of GLE. ${ }^{a, b, c, d, e}$ Means in the same column with different superscripts differ significantly $(\mathrm{p}<0.05)$ 


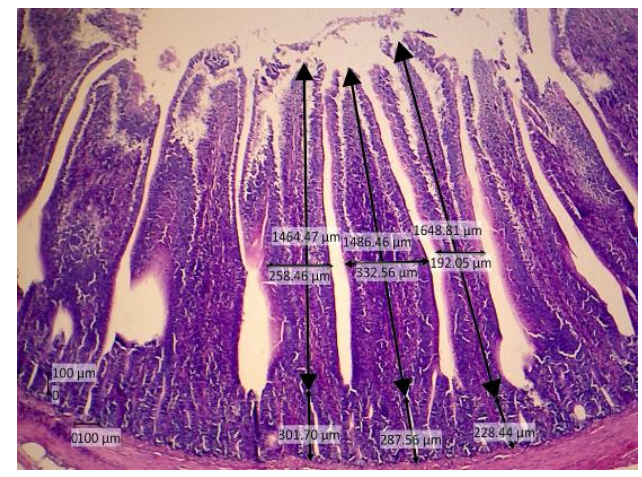

(a)

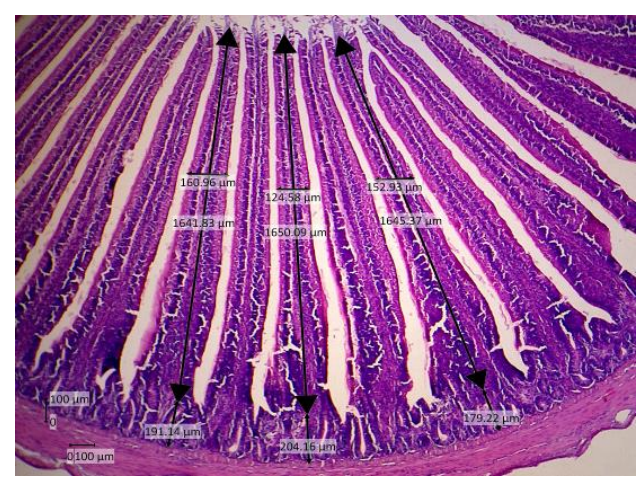

(c)

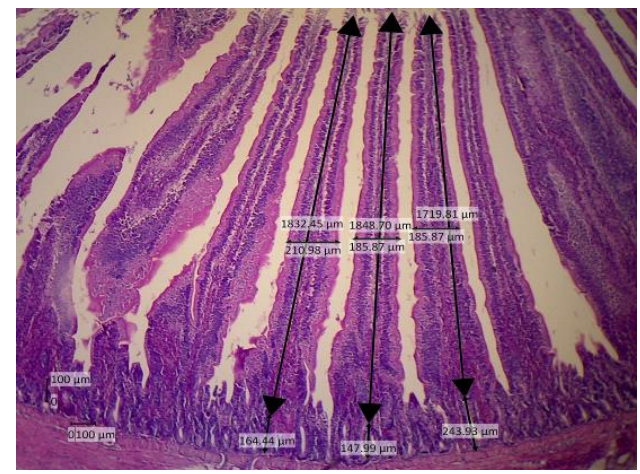

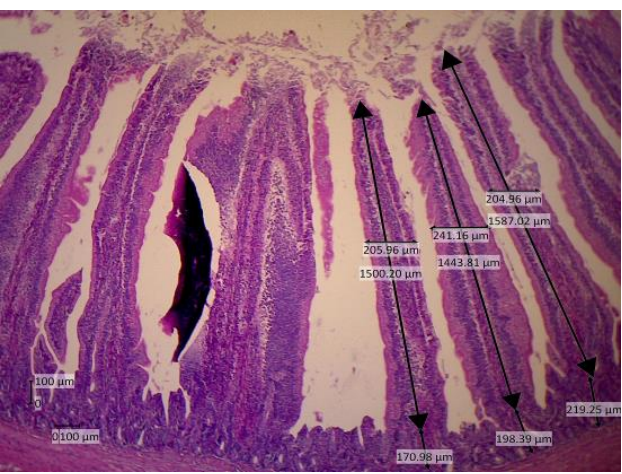

(b)

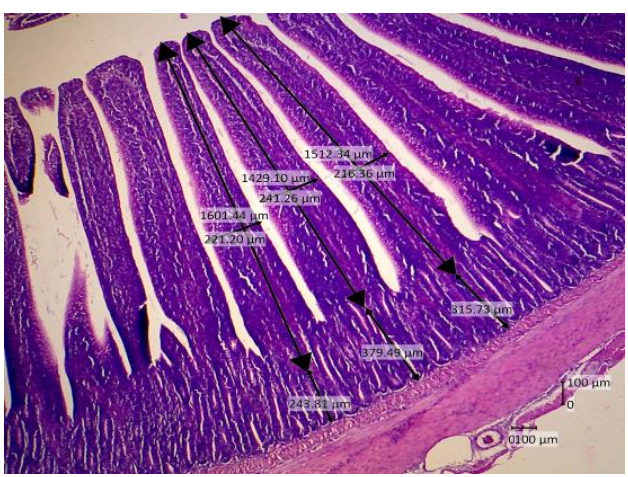

(d)

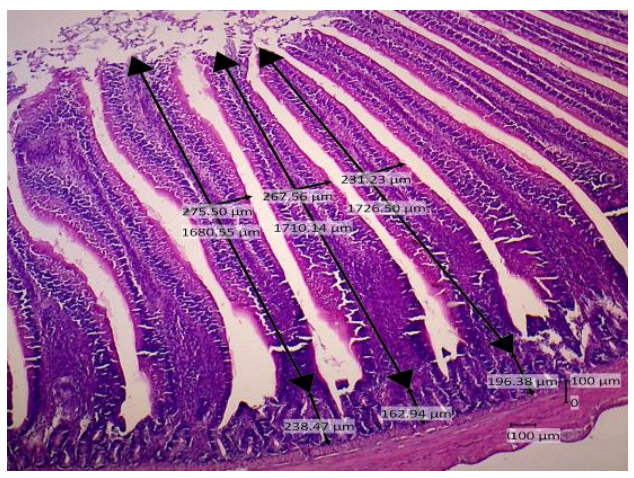

Figure 1. Sections of jejunum morphology of broiler chicken supplemented with nano-encapsulated graviola leaf extract (GLE). (a) T1= drinking water without feed additive as a negative control, (b) $\mathrm{T} 2=$ drinking water + Tetracycline $25 \mathrm{mg} / \mathrm{L}$ drinking water as positive control, (c) T3= drinking water $+15 \mathrm{~mL} / \mathrm{L} \mathrm{GLE}$, (d) T4= drinking water $+30 \mathrm{~mL} / \mathrm{L}$ GLE, (e) T5= drinking water $+15 \mathrm{~mL} / \mathrm{L}$ nano-encapsulation of GLE, and (f) T6= drinking water $+30 \mathrm{~mL} / \mathrm{L}$ nano-encapsulation of GLE.

also decrease, which will be beneficial in improving the micro-morphology of the intestinal villi and micronutrient absorption by the intestinal cell wall. The increased availability of micronutrients increases the utilization of nutrients as precursors for carcass production so that that bodyweight gain can be increased and growth performance becomes more optimal (Hernández et al., 2006; Dono, 2013).

\section{Microbial Populations}

The increase of LAB in the present study agreed with the previous study (Ningsih et al., 2019) who found that supplementation of encapsulated Phyto biotic increased the population of $\mathrm{LAB}$ in the intestine broiler chickens. Rehman et al. $(2007 a, b)$ reported that lactic acid bacteria improved gastrointestinal function, nutrients digestibility, and animal performance. Lactic acid bacteria may also produce organic acids and other antibacterial substances (Neal-McKinney et al., 2012). Furthermore, Rahimi et al. (2011) reported that bioactive compounds in herbs, such as flavonoids, phenol, and alkaloids, may improve the growth of lactic acid bacteria and bifidobacterial populations and inhibited coliform bacteria. Antibiotics and Phyto biotics may control and limit the growth and colonization of various pathogenic bacteria in the gut of chicks (Ferket, 2004). These effects are due to interference in cell wall synthesis, changes in 
the permeability of the cytoplasmic membrane, interference in the cell protein synthesis, and interference in the chromosome replication (Mellor, 2000). More balanced microflora colonization in the poultry gastrointestinal tract could lead to greater efficiency in digestibility and feed utilization, resulting in enhanced feed efficiency and maximized growth of host animals (Ferket, 2004).

\section{Jejunal Morphology}

The addition of NGLE in the drinking water of broiler chicken contributed to improving villus height and width, and crypt depth ratio (Table 6). The antibacterial activity of NGLE could be attributed to the decreased intestinal $\mathrm{pH}$, reduced pathogenic bacteria populations, which in turn will be beneficial to improve the jejunal villi. The increased villus height in the current study might have respectable contributions to enhancing absorptive surface area for better nutrients and energy utilization (Adil et al., 2010). Abdel-Rahman et al. (2014) and Debnath et al. (2014) similarly reported that supplementation of herbal products improved intestinal morphology, enhanced villus height and surface area, resulting in better gut health in broiler chickens. The depth of the jejunal crypt in the present study was similar between groups. These findings should be favorable as a small crypt produced longer villus. As reported by Petrolli et al. (2012), the crypts were responsible for the production of enterocytes required for villi renewal. The more the crypt is demanded in terms of cell renewal, the greater its depth. Therefore, this indicated that supplementations of nano-encapsulated GLE through drinking water were beneficial to maximize the production of absorptive cells in the small intestine, which might be a good indicator of better gut health. The beneficial effects on jejunal morphology attributed to the antibacterial action of nano-encapsulated GLE, decrease the inflammatory reactions at the mucosa, facilitate better villus growth, increase the nutrients utilization, and improve the growth performance broiler chickens (Mahmood et al., 2015).

\section{CONCLUSION}

Supplementation of $15 \mathrm{~mL} / \mathrm{L}$ NGLE improved jejunal morphology, jejunal LAB, and growth performance of broiler chickens. Dosage up to $30 \mathrm{~mL} / \mathrm{L}$ of NGLE was not different from the drinking water supplemented with NGLE at a dose of $15 \mathrm{~mL} / \mathrm{L}$. The reduced coliform bacteria populations in the jejunum, increased jejunal LAB population, and improved jejunal morphology suggests that NGLE might be an alternative for antibiotics growth promoters in poultry.

\section{CONFLICT OF INTEREST}

We certify that there is no conflict of interest with any financial, personal, or other relationships with other people or organizations related to the material discussed in the manuscript.

\section{ACKNOWLEDGEMENT}

We acknowledge financial support from Research Directorate of Universitas Gadjah Mada, Yogyakarta, Indonesia with grant number 3284/UN1/DITLIT/ DIT-LIT/LT/2019.

\section{REFERENCES}

Abdel-Rahman, H. A., S. I. Fathallah, \& A. A. Helal. 2014. Effect of turmeric (Curcuma longa), fenugreek (Trigonella foenum-graecum L.) and/or bioflavonoid supplementation to the broiler chicks diet and drinking water on the growth performance and intestinal morphometeric parameters. Glob. Vet. 12:627-635.

Adil, S., M. T. Banday, G. A. Bhat, M. S. Mir, \& M. Rehman. 2010. Effect of dietary supplementation of organic acids on performance, intestinal, histomorphology and serum biochemistry of broiler chicken. Vet. Med. Int. 479485:1-7. https://doi.org/10.4061/2010/479485

Alonge, E. O., D. Eruvbetine, O. M. O. Idowu, A. O. Obadina, \& O. O. Olukomaiya. 2017. Comparing the effects of the supplementary antibiotic, probiotic, and prebiotic on carcass composition, salmonella counts and serotypes in droppings and intestine of broiler chickens. Poult. Sci. J. 5:41-50.

Amalia, Z., \& W. Adisasmito. 2017. Analysis of policy making factors on the prohibition of hormones and antibiotics use for feed as a public health protection. J. Indon. Health Pol. Admin. 2:14-19. https://doi.org/10.7454/ihpa.v2i2.1900

Bonifácio, B. V., P. B. Silva, M. A. Ramos, K. M. Negri, T. M. Bauab, \& M. Chorilli. 2014. Nanotechnology-based drug delivery systems and herbal medicines: a review. Int. J. Nanomed. 9:1-15. https://doi.org/10.2147/IJN.S52634

Buzea, C., I. I Pacheco \& K. Robbie. 2007. Nanomaterials and nanoparticles: sources and toxicity. Biointerphases 2:17-71. https://doi.org/10.1116/1.2815690

Calvo, P., C. Remũnán-López, J. L. Vila-Jato, \& M. J. Alonso. 1997. Novel hydrophilic chitosan-polyethylene oxide nanoparticles as protein carriers. J. Appl. Polym. Sci. 63:125-132. https://doi.org/10.1002/(SICI)10974628(19970103)63:1<125::AID-APP13>3.0.CO;2-4

Cherkasov, A., K. Hilpert, H. Jenssen, C. D. Fjell, M. Waldbrook, S. C. Mullaly, R. Volkmer, \& R. E. W. Hancock. 2008. Use of artificial intelligence in the design of small peptide antibiotics effective against a broad spectrum of highly antibiotic-resistant superbugs. Acs. Chem. Biol. 4:65-74. https://doi.org/10.1021/cb800240j

Correa-Gordillo, J., J. Ortiz, M. Sa'nchez-Mejı'a, \& H. Pacho'n. 2012. Actividad antioxidante en guana'bana (Annona muricata L.) una revisio'n bibliogra'fica. Bol. Latinoam. Caribe Plant. Med. Aromat. 11:111-126.

Debnath, B. C., K. B. D. Choudhary, K. Ravikanth, A. Thakur, \& S. Maini. 2014. Comparative efficacy of natural growth promoter with antibiotic growth promoter on growth performance and intestinal morphometry in broiler birds. Int. J. Pharmacol. Sci. Health Care. 4:155-168.

Dei, H. K., S. P. Rose, A. M. Mackenzie, \& R. Amarowicz. 2008. Growth performance of broiler chickens fed diets containing shea nut (Vitellaria paradoxa, Gaertn.) meal fermented with Aspergillus niger. Poult. Sci. 87:1773-1778. https://doi. org/10.3382/ps.2008-00055

Dono, N. D. 2013. Turmeric (Curcuma longa Linn.) supplementation as an alternative to antibiotics in poultry diets. Wartazoa 23:41-49. https://doi.org/10.14334/wartazoa. v23i1.958

Fascina, V.B., J. R. Sartori, E. Gonzales, F. B. D. Carvalho, I. M. G. P. D. Souza, G. V. Polycarpo, A. C. Stradiotti, \& 
V. C. Pelícia. 2012. Phytogenic additives and organic acids in broiler chicken diets. Rav. Bras. Zootec. 41:2189-2197. https://doi.org/10.1590/S1516-35982012001000008

Ferket, P. R. 2004. Alternatives to antibiotics in poultry production. In: Lyons TP, Jacques KA (eds), Nutritional Biotechnology in the Feed and Food Industries. E-publishing Inc, Nottingham, UK. pp. 57-67.

Gharechopogh, A. M., J. Fakhraei, S. A. Hosseini, H. M. Yarahmadi, \& H. Lotfollahim. 2021. Performance, immune responses, and blood biochemistry of broiler chickens fed with plant growth compound. Trop. Anim. Sci. J. 44:62-70. https://doi.org/10.5398/tasj.2021.44.1.62

Gavamukulya, Y., F. Aboi-Elella, F. Wamunyokoli, \& H. AEIShemy. 2014. Phytochemical screening, anti-oxidant activity and in vitro anticancer potential of ethanolic and water leaves extracts of Annona muricata (Graviola). Asian Pacific J. Trop. Med. 7:S355-S363. https://doi.org/10.1016/ S1995-7645(14)60258-3

George, V. C., D. R. Kumar, P. K. Suresh, \& R. A. Kumar. 2014. Antioxidant, DNA protective efficacy and HPLC analysis of Annona muricata (soursop) extracts. J. Food Sci. Technol. 52:2328-2335. https://doi.org/10.1007/s13197-014-1289-7

George, V. C., D. R. Kumar, V. Rajkumar, P. K. Suresh, \& K. Ashok. 2012. Quantitative assessment of the relative antineoplastic potential of the n-butanolic leaf extract of Annona muricata Linn. In normal and immortalized human cell lines. Asian Pac. J. Cancer Prev. 13:699-704. https://doi. org/10.7314/APJCP.2012.13.2.699

Hamizah, S., A. H. Roslida, O. Fezah, K. L. Tan, Y. S. Tor, \& C. I. Tan. 2012. Chemopreventive potential of Annona muricata L. leaves on chemically-induced skin papillomagenesis in mice. Asian Pac. J. Cancer Prev. 13:2533-2539. https://doi.org/10.7314/APJCP.2012.13.6.2533

Hassan, M. M., S.A. Khan, A. H. Shaikat, Md. E. Hossain, Md. A. Hoque, Md. H. Ullah, \& S. Islam. 2013. Analgesic and anti-inflammatory effects of ethanol extracted leaves of selected medicinal plants in animal model. Vet. World. 6:6871. https://doi.org/10.5455/vetworld.2013.68-71

Helfer, M., H. Koppensteiner, M. Schneider, S. Rebensburg, S. Forcisi, C. Mu"ller, \& R. Brack-Werner. 2014. The root extract of the medicinal plant Pelargonium sidoides is a potent HIV-1 attachment inhibitor. PLoS ONE. 29:e87487. https://doi.org/10.1371/journal.pone.0087487

Hernández, F., V. García, J. Madrid, J. Orengo, P. Catalá, \& M. D. Megías. 2006. Effect of formic acid on performance, digestibility, intestinal histomorphology and plasma metabolite levels of broiler chickens. Br. Poult. Sci. 47:50-56. https://doi.org/10.1080/00071660500475574

Hosseini, S., M. Chamani, A. Seidavi, A.A.Sadeghi, \&Z. AnsariPirsareai. 2017. Effect of feeding Thymolina ${ }^{\circledR}$ powder on the carcass characteristics and morphology of small intestine in Ross 308 broiler chickens. Acta. Sci. 39:45-50. https://doi.org/10.4025/actascianimsci.v39i1.32074

Jiwuba,P.C., T.T.Kuka, O.E. Kadurumba, \& C.O.Nwachukwu. 2017. Evaluation of haematological and serum biochemical characteristics of Annona muricata (Sour Sop) leaf extract on broiler birds. Int. J. Res. Stud. Microbiol. Biotechnol. 3:6-11. https://doi.org/10.20431/2454-9428.0304003

Leusink, G., H. Rempel, B. Skura, M. Berkyto, W. White, Y, Yang, J. Y. Rhee, S. Y. Xuan, S. Chiu, F. Silversides, S. Fitzpatrick \& M. S. Diarra. 2010. Growth performance, meat quality, and gut microflora of broiler chickens fed with cranberry extract. Poult. Sci. 89:514-1523. https://doi. org/10.3382/ps.2009-00364

Mahmood, S., A. Rehman, M. Yousaf, P. Akhtar, G. Abbas, K. Hayat, A. Mahmood, \& M. K. Shahzad. 2015. Comparative efficacy of different herbal plant's leaf extract on haematology, intestinal histomorphology and nutrient digestibility in broilers. Adv. Zool. Bot. 3:11-16. https://doi. org/10.13189/azb.2015.030201

Mellor, S. 2000. Alternatives to antibiotic. Pig Progress 16:18-21.

Moghadamtousi, S. Z., E. Rouhollahi, H. Karimian, M. Fadaeinasab, M. Firoozinia, M. Ameen Abdulla, \& H. Abdul Kadir. 2015. The chemopotential effect of Annona muricata leaves against azoxymethane-induced colonic aberrant crypt foci in rats and the apoptotic effect of acetogenin annomuricin E in HT-29 aells: a bioassay-guided approach. PLoS ONE 10:e0122288. https://doi.org/10.1371/ journal.pone. 0122288

Monigatti, M., R. W. Bussmann, \& C. S. Weckerle. 2013. Medicinal plant use in two Andean communities located at different altitudes in the Bolı'var Province, Peru. J. Ethnopharmacol. 145:450-464. https://doi.org/10.1016/j.jep.2012.10.066

Nawwar, M., N. Ayoub, S. Hussein, A. Hashim, R. ElSharawy, K. Wende, M. Harms, \& U. Lindequist. 2012. A flavonol triglycoside and investigation of the antioxidante and cell stimulating activities of Annona muricata Linn. Arch. Pharmacal Res. 35:761-767. https://doi.org/10.1007/ s12272-012-0501-4

Neal-McKinney, J. M., X. Lu, T. Duong, C. L. Larson, D. R. Call, D. H. Shah, \& M. E. Konkel. 2012. Production of organic acids by Probiotic Lactobacilli can be used to reduce pathogen load in poultry. PLoS ONE 7:1-11. https://doi. org/10.1371/journal.pone.0043928

Ningsih, N., B. Ariyadi, N. D. Dono. Supadmo, \& Zuprizal. 2019. The effect of nanoencapsulated Phaleria macrocarpa fruits extract in drinking water on jejunal histomorphology of broiler chickens. Trop. Anim. Sci. J. 42:106-112. https://doi.org/10.5398/tasj.2019.42.2.106

Nouri, A. 2019. Chitosan nano-encapsulation improves the effects of mint, thyme, and cinnamon essential oils in broiler chickens. Br. Poult. Sci. 60:530-538. https://doi.org/10.1080/00071668.2019.1622078

Petrolli, T. G., L. F. T. Albino, H. S. Rostagno, P. C. Gomes, F. Tavernari, \& E. M. Balbino. 2012. Herbal extracts in diets for broilers. R. Bras. Zootech. 41:1683-1690. https://doi. org/10.1590/S1516-35982012000700018

Pieme, C., S. Kumar, M. Dongmo, B. Moukette, F. Boyoum, J. Ngogang, \& A. Saxena. 2014. Antiproliferative activity and induction of apoptosis by Annona muricata (Annonaceae) extract on human cancer cells. BMC Complement. Altern. Med. 14:514-516. https://doi.org/10.1186/1472-6882-14-516

Radji, M., M. Kurniati, \& A. Kiranasari. 2015. Comparative antimycobacterial activity of some Indonesian medicinal plants against multi-drug resistant Mycobacterium tuberculosis. J. App. Pharm. Sci. 5:19-22.

Rahimi, S., Z. T. Zadeh, M. A. K. Torshizi, R. Omidbaigi, \& H. Rokni. 2011. Effect of the three herbal extracts on growth performance, immune system, blood factors and intestinal selected bacterial population in broiler chickens. J. Agr. Sci. Tech. 13:527-539.

Rehman, H., C. Rosenkranz, J. Bhm, \& J. Zentek. 2007a. Dietary inulin affects the morphology but not the sodium dependent glucose and glutamine transport in the jejunum of broilers. Poult. Sci. 86:118-122. https://doi.org/10.1093/ ps/86.1.118

Rehman H., W. Vahjen, W. A. Awad, \& J. Zentek. 2007b. Indigenous bacteria and bacterial metabolic products in the gastrointestinal tract of broilers. Arch. Anim. Nutr 61:319-335. https://doi.org/10.1080/17450390701556817

Rice-Evans C. A., N. J. Miller, P. G. Bolwell, P. M. Bramley, \& J. B. Pridham. 1995. The relative activities of plant-derived polyphenolic flavonoid. Free radical Res. 22:375-383. https://doi.org/10.3109/10715769509145649

Ross, I. A. 2010. Medicinal Plants of the World. $2^{\text {nd }}$ ed. Chemical Constituents, Traditional and Modern Medicinal, vol. 1. Humana Press, Totowa. pp. 133-142. 
Saraf, A. S. 2010. Applications of novel drug delivery system for herbal formulations. Fitoterapia 81:680-689. https://doi. org/10.1016/j.fitote.2010.05.001

Sari, D.P., T. S. Utami, R. Arbianti, \& H. Hermansyah. 2018. The effect of centrifugation speed and Chitosan-Sodium Tripolyphosphate ratio toward the nanoencapsulation of Sambiloto (Andrographis paniculata) for the formulation of Hepatitis B drug. IOP Conf. Ser. Earth Environ. Sci. 105:16. https://doi.org/10.1088/1755-1315/105/1/012112

Sen, S., S. L. Ingale, Y. W. Kim, J. S. Kim, K. H. Kim, \& J. D. Lohakare. 2012. Effect of supplementation of Bacillus subtilis LS 1-2 to broiler diets on growth performance, nutrient retention, caecal microbiology and small intestinal morphology. Res. Vet. Sci. 93:264-268. https://doi.org/10.1016/j. rvsc. 2011.05.021

Shang, H.M.,H.Song, Y.L.Xing, S. L. Niu, G.D.Ding, Y. Y.Jiang, \& F. Liang. 2016. Effects of dietary fermentation concentrate of Hericium caput-medusae (Bull.:Fr.) Pers. on growth performance, digestibility, and intestinal microbiology and morphology in broiler chickens. J. Sci. Food Agric. 96:215-222. https://doi.org/10.1002/jsfa.7084

Sofowora, L. A. 1993. Phytochemical Screening of Medicinal Plants and Traditional Medicine in Africa. 2nd Ed. Spectrum Books Limited Nigeria, pages 150-156.

Solomon-Wisdom, G. O., S. C. Ugoh, \& B. Mohammed. 2014. Phytochemical screening dan antimicrobial activities of Annona muricata (L) leaf extract. Am. J. Biol. Chem. Pharm. Sci. 2:1-7.

Sugayana, M., M. Magela, \& G. Rubalakshmi. 2016. New era about treatment-evaluation of anticancer properties of evergreen medicinal plant Annona muricata (Graviola). Int. J. Recent Sci. Res. 7:10954-10956.

Sugiharto, S. 2016. Role of nutraceuticals in gut healthand growth performance of poultry. J. Saudi Soc Agr. Sci. 15:99-111. https://doi.org/10.1016/j.jssas.2014.06.001

Sugiharto, S. \& S. Ranjitkar. 2019. Recent advances in fermented feeds towards improved broiler chicken performance, gastrointestinal tract microecology and immune responses: A review. Anim. Nutr. 5:1-10. https://doi.org/10.1016/j. aninu.2018.11.001

Thanh, N.T., T. C. Loh, H. L. Foo, M. Hair-Bejo, \& B. K. Azhar. 2009. Effects of feeding metabolite combinations produced by Lactobacillus plantarum on growth performance, faecal microbial population, small intestine villus height and faecal volatile fatty acids in broilers. Br. Poult. Sci. 50:298-306. https://doi.org/10.1080/00071660902873947

Vieira, G. H. F., J. A. Mourao, A. M. Angelo, R. A. Costa, \& R. H. S. D. F. Vieira. 2010. Antibacterial effect (in vitro) of Moringa oleifera and Annona muricata against gram positive and gram negative bacteria. Revista do Instituto de Medicina Tropical de Sao Paulo. 52:129-132. https://doi.org/10.1590/S0036-46652010000300003

Vijayameena, C., G. Subhashini, M. Loganayagi, \& B. Ramesh. 2013. Phytochemical screening and assessment of antibacterial activity for the bioactive compounds in Annona muricata. Int. J. Curr. Microbiol. App. Sci. 2:1-8.

Wachira, W. M., A. Shitandi, \& R. Ngure. 2011. Deternination of the limit detevtion of penicillin $G$ residues in poultry meat using a loww cost migrobiological method. Int. Food Res. J. 18:1203-1208. 